\title{
Sweet and sour sugars from the sea: the biosynthesis and remodeling of sulfated cell wall polysaccharides from marine macroalgae
}

\author{
Elizabeth Ficko-Blean ${ }^{1}$, Cecile Hervé1 \& Gurvan Michel1*
}

1 Sorbonne Université, UPMC Univ Paris 06, CNRS, UMR 8227, Integrative Biology of Marine Models, Station Biologique de Roscoff, CS 90074, 29688, Roscoff cedex, Bretagne, France

* Corresponding author: gurvan.michel@sb-roscoff.fr

With 7 figures and 1 table in the text and 1 table as electronic supplement

\begin{abstract}
The cell walls of green, red and brown seaweeds are dominated by the presence of sulfated polysaccharides. The recent genomic analyses of Chondrus crispus (Rhodophyta) and Ectocarpus siliculosus (Phaeophyceae) have revealed carbohydrate-active enzymes likely implicated in the biosynthesis of these polymers. The closest homologues of many of these algal enzymes are found in animals and are involved in the biosynthesis of sulfated glycosaminoglycans, indicating a shared ancestral pathway between animals, red and brown algae. Here, we review the structures of these algal sulfated polysaccharides and the current state of knowledge on the enzymes involved in their biosynthesis and remodeling. Based on the experimental and genomic data available, biosynthetic pathways for these essential cell wall polysaccharides are presented.
\end{abstract}

Keywords: seaweeds, sulfated polysaccharides, biosynthesis, genomics, ulvan, agar, carrageenan, fucoidan, glycoside hydrolase, glycosyltransferase

\section{Introduction}

The Archeaplastida phylum, which includes the Glaucophyta, the red algae (Rhodophyta), the green algae (Chlorophyta and Charophyta) and land plants, evolved after an ancient eukaryotic ancestor engulfed a photosynthetic cyanobacterium in a primary endosymbiotic event about 1500 million years ago (Yoon et al. 2004; Baldauf 2008). The Stramenopile phylum (which includes the Phaeophyceae or brown algae) evolved about 1000 million years ago after a secondary endosymbiosis event of a unicellular red alga ancestor by an ancestral protist (Yoon et al. 2004; Reyes-Prieto et al. 2007; Baldauf 2008). Thus, though the Archaeplastida and Stramenopiles phyla are non-monophyletic, they partly share a complex evolutionary history. In both phyla several algal lineages have independently developed complex multicellularity, giving rise to the green, red and brown marine macroalgae (or seaweeds). One important step in the development of multicellularity for these organisms is the evolution of the extracellular matrix, or cell wall (CW), which provides a basis for cellto-cell communication, cooperation and self-recognition (Brownlee 2002). The CW of plants and macroalgae is composed mainly of carbohydrates (Popper et al. 2011) and is essential for mechanical support, providing a physical barrier against osmotic pressure and pathogens. The CWs of marine macroalgae differ from those of land plants by the prevalence of matrix components rather than crystalline components, such as cellulose, and by the abundance of acidic (mainly sulfated) polysaccharides. The major known matrix sulfated polysaccharides produced by macroalgae are the red algal galactans (agars, carrageenans and porphyrans), the brown algal fucose-containing sulfated polysaccharides (FCSPs) and the green algal ulvans, galactans and arabinogalactans (Popper et al. 2011). The anionic matrix components lend unique properties to the marine macroalgae (Kloareg \& Quatrano 1988), in particular, sulfated polysaccharides provide a heavily hydrated surface which may help prevent desiccation during low tide conditions. Moreover, the gel like properties of these polysaccharides provide flexibility to the macroalgae which likely help the organisms to cope with the extreme physical forces exerted on them by the strong ocean currents. It has also been suggested that the sulfated algal CW protects against salinity variation (osmotic stress) (DeniaudBouet et al. 2014), heavy metal toxicity (Andrade et al. 2010), pH and temperature extremes (Ucko et al. 1989) and confers anti-oxidant properties (Tannin-Spitz et al. 2005; Arad \& Levy-Ontman 2010; Chen et al. 2010).

Understanding the biosynthesis and remodeling of sulfated algal polysaccharides has been hampered by the lack of genomic sequences for seaweeds. To date, no genome sequence for a green macroalga has been published, thus limiting the amount of information available. However, the 
recent genome sequencing of the red macroalga Chondrus crispus (Irish moss) (Collen et al. 2013) and of the brown alga Ectocarpus siliculosus (Cock et al. 2010) has revealed gene sequences encoding enzymes predicted to be active on the sulfated $\mathrm{CW}$ polysaccharides. After presenting the structures of the main sulfated polysaccharides of macroalgae we will review the recent advances on the metabolic pathways for these crucial algal polymers. Table 1 illustrates some of the enzyme functions which are expected to be required for sulfated polysaccharide biosynthesis and remodeling. Glycosyl transferases (GTs), which transfer a monosaccharide from an activated sugar molecule to an acceptor moiety, and glycoside hydrolases (GHs), which hydrolyze the glycosidic bond between a sugar molecule and another moiety, have been categorized into amino acid sequence based CAZyme (Carbohydrate Active Enzyme) families (Cantarel et al. 2008). The GTs are expected to be the main players in the biosynthetic pathways, while GHs are more likely involved in CW remodeling and recycling. There are additional enzymes which modify carbohydrate moieties, such as carbohydrate sulfotransferases (STs), which add a sulfo group from a donor molecule (often 3'phosphoadenosine5 'phosphosulfate, PAPS), and sulfatases, which remove a sulfate group. We will also discuss a class of enzymes unique to red macroalgae: galactose-6-sulfurylases, which catalyze the formation of the 3,6-anhydrogalactose moiety through the removal of the C6 sulfate group in sulfated galactans. There are also other carbohydrate modifying enzymes (such

Table 1. Enzyme functions required for sulfated polysaccharide biosynthesis and remodeling

\begin{tabular}{|c|c|}
\hline Enzyme & Function \\
\hline $\begin{array}{l}\text { Galactosyl } \\
\text { transferases (GTs) }\end{array}$ & $\begin{array}{l}\text { use (for the most part) nucleotide- } \\
\text { activated sugars as donors and catalyse } \\
\text { the transfer of the activated donor } \\
\text { glycoside to an acceptor moiety to } \\
\text { synthesize the glycan chain }\end{array}$ \\
\hline $\begin{array}{l}\text { Sulfotransferases } \\
\text { (STs) }\end{array}$ & $\begin{array}{l}\text { act by adding a sulfo groups from a donor } \\
\text { molecule, often } 3 \text { 'phosphoadenosine- } \\
5 \text { 'phosphosulfate (PAPS), to a glycoside } \\
\text { receptor }\end{array}$ \\
\hline $\begin{array}{l}\text { Glycoside } \\
\text { Hydrolases (GHs) }\end{array}$ & $\begin{array}{l}\text { cleave the glycosidic bond through the } \\
\text { addition of water molecule }\end{array}$ \\
\hline Sulfatases & catalyse the hydrolysis of sulfate esters \\
\hline $\begin{array}{l}\text { Galactose-6- } \\
\text { sulfurylases }\end{array}$ & $\begin{array}{l}\text { catalyse the formation of the unusual } \\
\text { bicyclic sugar 3,6-anhydrogalactose } \\
\text { through removal of the C6 sulfate group } \\
\text { from galactose. These enzymes are } \\
\text { unique to red algae }\end{array}$ \\
\hline Other enzymes & $\begin{array}{l}\text { which are beyond the scope of this } \\
\text { review, including methyltransferases, } \\
\text { acetyltransferases, epimerases, etc... }\end{array}$ \\
\hline
\end{tabular}

as methyltransferases, acetyltransferases and epimerases) which are beyond the scope of this review. To date, most of the experimental knowledge on enzymes specific for algal sulfated polysaccharides has been obtained from marine bacteria which use these polymers as carbon sources. Several reviews have discussed different aspects of this topic (Michel et al. 2006; Hehemann et al. 2014; Martin et al. 2014) and we will not detail these marine bacterial enzymes here. Nevertheless, examination into the sequenced algal genomes reveals few candidate proteins related to these bacterial enzymes (Supplementary Table 1). Moreover, these proteins are already precious tools for characterizing the structure of algal sulfated polysaccharides (Greer \& Yaphe 1984; Colin et al. 2006; Correc et al. 2011; Silchenko et al. 2013) and will surely be essential in the near future in order to provide oligosaccharide substrates for assaying the candidate algal enzymes discussed in this review.

\section{Green algae}

Within the Chlorophyta green algae the marine class Ulvophyceae synthesizes complex sulfated branched polysaccharides. The genera Ulva, Monostroma, Gayralia, and Acetabularia synthesize the highly anionic ulvan polysaccharides (sulfated glucuronorhamnoxyloglycans)

\section{ulvanobiuronic acid 3-sulfate A}

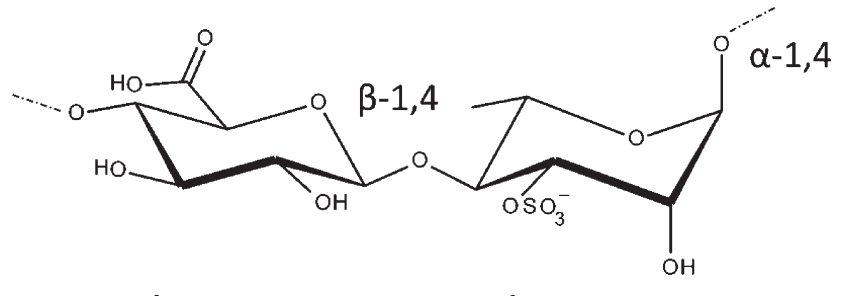

${ }^{4} C_{1}$ D-glucuronic acid $\quad{ }^{1} C_{4}$ L-rhamnose

\section{ulvanobiuronic acid 3-sulfate B}

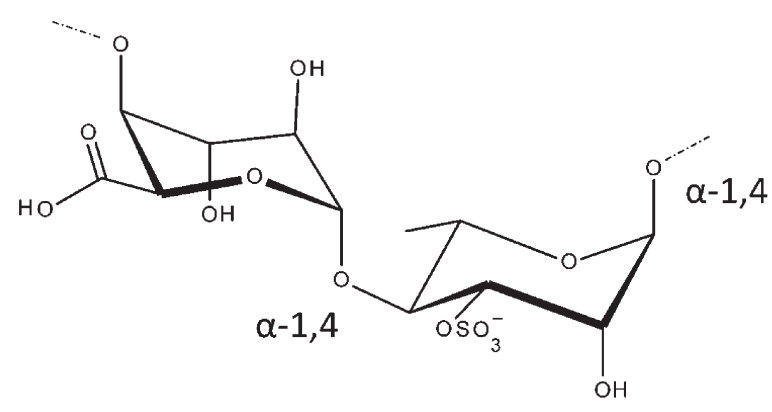

$$
{ }^{1} \mathrm{C}_{4} \text { L-iduronic acid }{ }^{1} \mathrm{C}_{4} \text { L-rhamnose }
$$

Fig. 1. Structures of the major disaccharide units found in ulvan. 
(Domozych et al. 2012). The complex ulvan polysaccharides consist of D-glucuronic acid, L-iduronic acid, L-rhamnose, D-glucose and a lesser amount of D-xylose residues (Brading et al. 1954; Percival \& Wold 1963; Lahaye et al. 1999; Cassolato et al. 2008). Sulfurylations on the 2 position of D-xylose have been detected; however, most ulvan sulfurylations occur as L-rhamnose-3-sulfate within the polysaccharide chain (Lahaye 1998; Lahaye et al. 1999; Lahaye \& Robic 2007). Lahaye et al. investigated the structure of ulvan from different Ulva species and identified two major disaccharide types (Lahaye et al. 1999). The first is ulvanobiuronic acid 3-sulfate A (Fig. 1) with the $\alpha$-1,4-linked repeating unit $\mathrm{D}$-glucuronic acid- $\beta$-1,4-L-rhamnose-3-sulfate. The second is ulvanobiuronic acid 3-sulfate B (Fig. 1) with the $\alpha$-1,4linked repeating unit L-iduronic acid- $\alpha-1,4-\mathrm{L}-$ rhamnose3 -sulfate. Analysis of ulvan from Ulva rigida revealed L-rhamnose residues with branching O2 D-glucuronic acid residues (Lahaye \& Ray 1996).

The genera Caulerpa, Codium and Bryopsis synthesize sulfated polysaccharides with limiting amounts of uronic acid residues (Domozych et al. 2012) and with the chief monosaccharide components galactose, arabinose and some- times xylose (Bilan et al. 2007; Chattopadhyay et al. 2007; Ciancia et al. 2012; Fernandez et al. 2014). Codium species produce three distinct structures of these uronic acid-poor sulfated polysaccharides. The first is a sulfated proteoglycan, isolated from Codium pugniformis, composed mainly of glucose but with minor amounts of galactose and arabinose (Matsubara et al. 2000). Strains of Codium also produce a pyruvated, sulfated and heavily branched galactan (Bilan et al. 2006; Bilan et al. 2007; Farias et al. 2008). In Codium yezoense this consists of 3-, 6- and 3,6-linked $\beta$-D-galactose residues with two branch points and two non-reducing termini for every seven galactose residues. Sulfurylations were found primarily on $\mathrm{O} 4$ and in lesser amounts on O6 of galactose. Pyruvations form mainly five-membered cyclic ketals with $\mathrm{O} 3$ and $\mathrm{O} 4$ and six-membered cyclic ketals in lesser amounts with O4 and O6 of galactose (Bilan et al. 2007). Finally, Codium also produces sulfated arabinans and/or arabinogalactan polysaccharides (Love \& Percival 1964; Uehara et al. 1992; Ciancia et al. 2007; Fernandez et al. 2013). Structural analysis on the pyruvated arabinogalactan sulfate from Codium fragile revealed sulfurylations on the $\mathrm{O} 2$ and/or $\mathrm{O} 4$ of 3-linked $\beta$-Larabinopyranose residues and $\mathrm{O} 4$ and/or $\mathrm{O} 6$ of the 3-linked

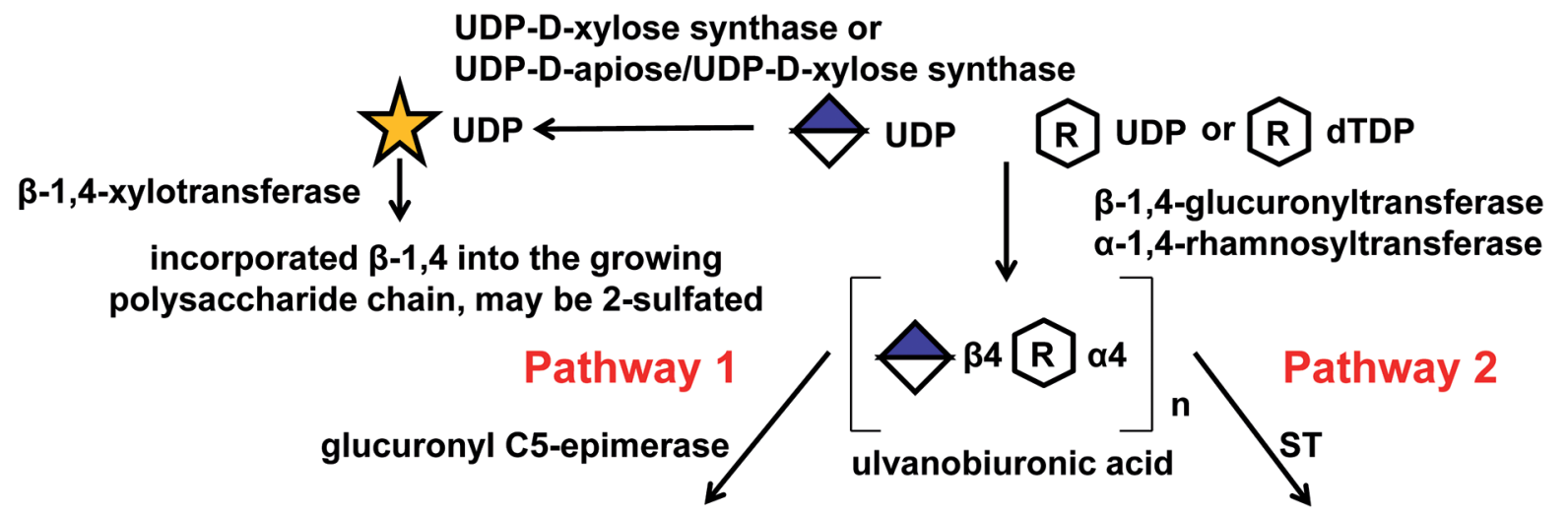

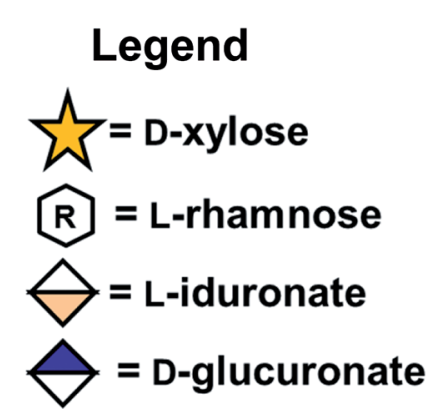

ulvanobiuronic acid $B$

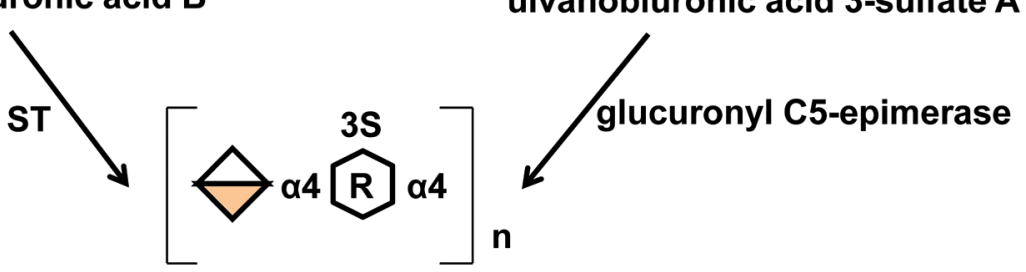

ulvanobiuronic acid 3-sulfate B

Fig. 2. Proposed activities involved in the ulvan biosynthesis pathway. Two suggested biosynthetic pathways are shown based on the schema initially proposed by Lahaye and Robic (Lahaye \& Robic 2007); however, none of the enzyme activities shown in the figure have been described experimentally in ulvan producing green algae. Abbreviations are as follows: UDP, uridine 5'-diphosphate; dTDP, thymidine 5'-diphosphate. 
$\beta$-D-galactose residues (Estevez et al. 2009). The terminal $\beta$-D-galactose moieties were mainly pyruvated on $\mathrm{O} 3$ and $\mathrm{O} 4$ forming five-membered cyclic ketal rings and branches were found on $\mathrm{O} 6$ of some of the 3-linked $\beta$-D-galactose moieties.

Little is known on the enzymatic systems produced by green algae for sulfated polysaccharide biosynthesis and remodeling, though Lahaye \& Robic propose a pathway for the biosynthesis of ulvan and predicted cell localization of the enzyme activities (Lahaye \& Robic 2007). Only two ulvan lyases (produced by marine bacteria) have been described in the literature (Lahaye et al. 1997; Collen et al. 2014). This reflects the limited knowledge available without an annotated genome sequence with which to identify interesting enzyme targets leading to functional/biochemical analyses. Without a genome we are left to predict enzyme activities that would be expected to be produced by green algae for sulfated polysaccharide biosynthesis (Fig. 2). For ulvan these activities would include $\alpha$-1,4-rhamnosyltransferase, $\beta$-1,4-glucuronyltransferase, glucosyltransferase, xylosyltransferase, glucuronyl C5-epimerase and carbohydrate ST activity. Finally, based on the evolutionary relationship of the red and brown algal enzymes involved in sulfated polysaccharide biosynthesis to animal enzymes (Michel et al. 2010), we might anticipate that many of the green algal CAZymes active on sulfated polysaccharides share this interesting phylogenetic history as well.

\section{Red algae}

Sulfated galactans are common to the $\mathrm{CW}$ of red algae. These polysaccharides consist of a linear backbone of galactose residues linked by alternating $\beta-1,4$ and $\alpha-1,3$ glycosidic bonds. The red algal seaweeds have been subdivided into either agarophyte or carrageenophyte algae based on the stereochemistry of the remarkable bicyclic $\alpha-3,6-$ anhydrogalactose moiety in their galactan chain, which is in the L-configuration in agars and in the D-configuration in carrageenans (Rees 1969).

The regular structure of the agar backbones is often masked by various chemical modifications, such as ester sulfate groups, methyl groups, or pyruvic acid acetal groups (Lahaye et al. 1989; van de Velde et al. 2002). The main agar repeating moiety is agarobiose (Fig. 3): D-galactose$\beta-1,4-(3,6)$-anhydro-L-galactose, referred to as G-LA in Knutsen's nomenclature (Knutsen et al. 1994). Another frequent modification is the sulfurylation on the $\mathrm{O} 6$ of the $\mathrm{L}$-galactose residues resulting in $\alpha$-L-galactose-6-sulfate (L6S). This L6S monomer is twice more abundant than LA in the agar extracted from Porphyra species (Anderson \& Rees 1965). This agar is commonly named porphyran and its main repeating unit is porphyranobiose (G-L6S) (Fig. 3). G-L6S units are found in various amounts in the agars of most agarophytes, including Gracilaria and Gelidium spp. (Hehemann et al. 2010). In agars, porphyranobiose units are commonly regarded as the precursors of agarobiose units.

\section{agarobiose}

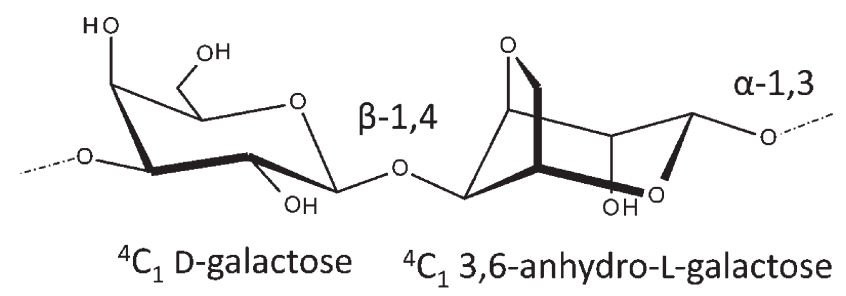

\section{porphyranobiose $\mathrm{R}=\mathrm{H}, \mathrm{CH}_{3}$}

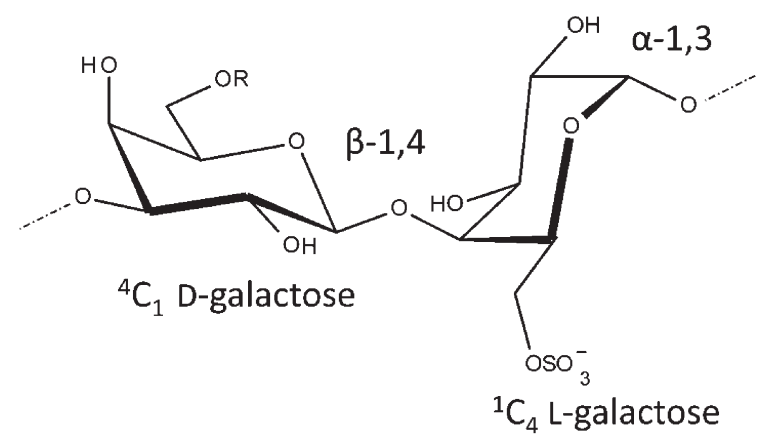

Fig. 3. Structures of the base disaccharide units of agars, agarobiose and porphyranobiose.

The structure of porphyran is further complicated by the frequent methylation of the $\mathrm{O} 6$ in the $\beta$-D-galactopyranose monomer (Lahaye et al. 1989; Correc et al. 2011).

As agars, carrageenans have very complex chemical structures depending on the algal source, life stage, and extraction procedure (Craigie 1990; van de Velde 2008). Carrageenans are classified according to the number and the position of sulfate esters (S) and by the occurrence of 3,6-anhydro-bridges in the 4-linked $\alpha$-D-galactose residues (DA unit) found in gelling carrageenans. The main disaccharide repeating units of the three most industrially exploited carrageenans, are the kappa-carrabiose (G4S-DA), the iota-carrabiose (G4SDA2S) and the lambda-carrabiose (G2S-D2S6S) (Knutsen et al. 1994) (Fig. 4). These processed polymers are mainly composed of one type of repeating unit and are commonly referred to kappa-, iota- and lambda-carrageenans, respectively. In contrast, native carrageenans have hybrid structures, with varying ratios of carrabiose motifs (Greer \& Yaphe 1984; Guibet et al. 2008). Unprocessed carrageenans also contain mu-carrabiose (G4S-D6S) and nu-carrabiose (G4S-D2S6S) units (Fig. 4), which are considered as the biosynthetic precursors of kappa- and iota-carrabiose-units, respectively (van de Velde et al. 2002). 

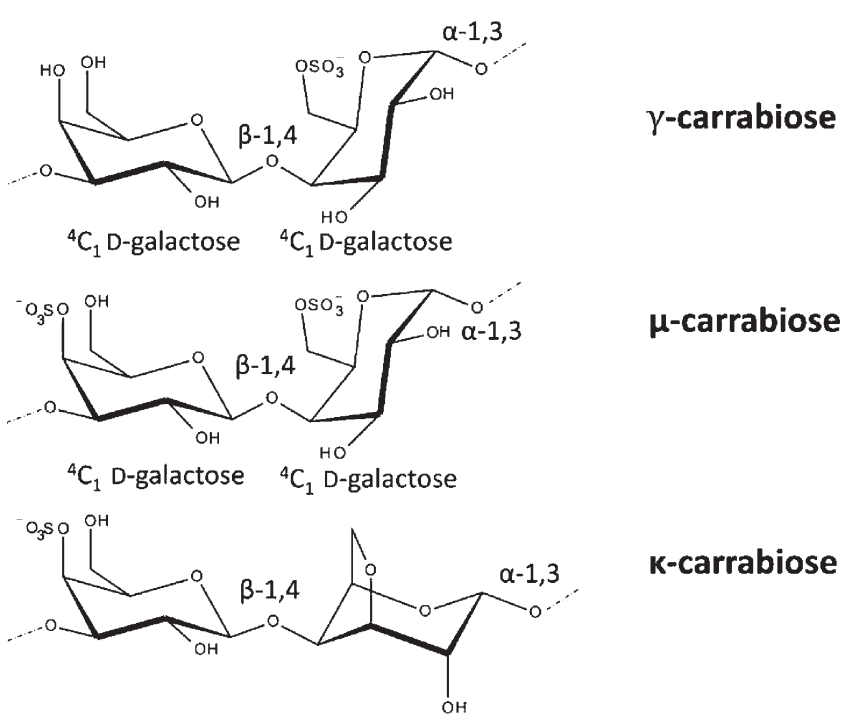

$\mu$-carrabiose

K-carrabiose

v-carrabiose
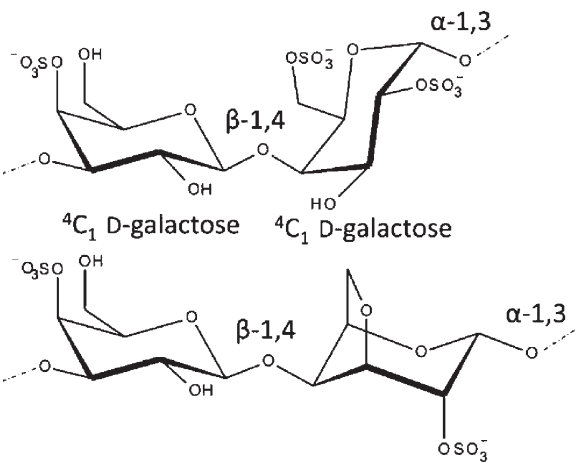

l-carrabiose

${ }^{4} C_{1}$ D-galactose ${ }^{1} C_{4}$ 3,6-anhydro-D-galactose

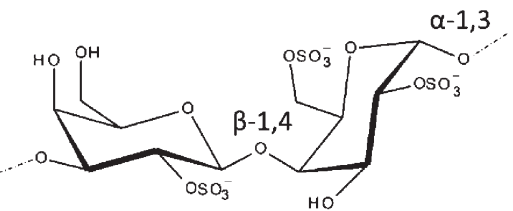

$\lambda$-carrabiose

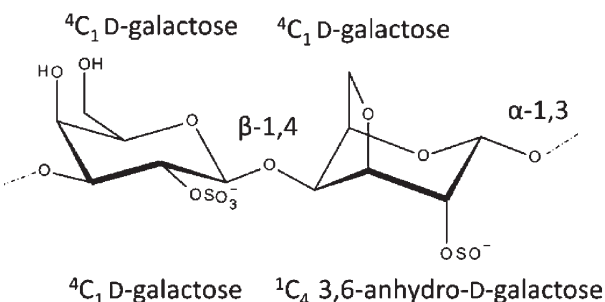

$\theta$-carrabiose

Fig. 4. Structures of the repeating disaccharide units in carrageenans.

As with land plants, the amorphous red algal matrix polysaccharides are expected to be interconnected by crystalline polysaccharides. Yet they represent a small portion of the wall, and very little is known on the nature of these polysaccharides. Cellulose fibrils are the most commonly found polymer, but additional hemicellulosic components have been described. In the carrageenophyte red alga Kappaphycus alvarezii, glucomannans and $\mathrm{O} 6$ sulfated mixed-linked glucans have been characterized (Lechat et al. 2000). In some agarophytes the gametophytic phase lacks cellulose, which is substituted by crystalline $\beta-1,4-\mathrm{D}$-mannans or $\beta-1,3-\mathrm{D}$ xylans (Kloareg \& Quatrano 1988; Craigie 1990). Palmaria palmata is a peculiar case within the red algae in having CWs almost exclusively composed of mixed-linked xylans (Deniaud et al. 2003; Lahaye et al. 2003). Mixed-linked xylans were also found in the order Nemaliales (Viana et al. 2011) and sulfated xylomannans were found in the red seaweed Sebdenia polydactyla (Ghosh et al. 2009). These analyses reveal apparent differences in $\mathrm{CW}$ structure even between closely related organisms. As an additional layer of complexity in the structures of red algal galactans, the carrageenophyte seaweeds, belonging to the Gigartinaceae and Phyllophoraceae families, have minor to significant amounts of sulfated agars and/or sulfated DL-galactan hybrids (Ciancia et al. 1993; Ciancia et al. 1997; Stortz et al. 1997; Estevez et al. 2001; Estevez et al. 2004). Furthermore, some agarophyte seaweeds also have small amounts of DL-hybrid structures (Takano et al. 1999; Errea \& Matulewicz 2003; Navarro \& Stortz 2003; Takano et al. 2003). Finally, monosaccharide composition analysis revealed the two main monosaccharides present in carrageenan and agar are galactose and 3,6-anhydrogalactose but that xylose, glucose and uronic acids may also be present in significant amounts (Jol et al. 1999; Bouhlal et al. 2011).

While marine bacterial enzymes have been characterized that degrade agars and carrageenans (Supplementary Table 1) (Michel et al. 2006; Hehemann et al. 2014; Martin et al. 2014), experimental knowledge on algal biosynthetic enzymes remains very limited. In 1961, Rees isolated an enzyme from Porphyra umbilicalis which removes the sulfate substituent from L-galactose-6-sulfate in porphyran and subsequently forms the anhydro bridge between C3 and C6 (Rees 1961). These enzymes are referred to as galactose6-sulfurylases and have also been identified in other red algae (Lawson \& Rees 1970; Zinoun et al. 1997). Notably, C. crispus contains a galactose-6-sulfurylase catalyzing the formation of 3,6-anhydro-D-galactose residues in the kappa family of carrageenans (Craigie \& Wong 1978; Wong \& Craigie 1978) and two different galactose-2,6-sulfurylases which specifically catalyze the conversion of nu-carrageenan into iota-carrageenan (Fig. 5) (Genicot-Joncour et al. 2009).

C. crispus, which has been pivotal for the characterization of the galactose-6-sulfurylase, is an abundant carrageenophyte red macroalga found in the northern Atlantic Ocean. It can grow up to $15 \mathrm{~cm}$ in length and is a major source of commercial carrageenan. The ecologic and economic interests of this species explain the abundance of scientific literature on C. crispus and the recent effort to obtain the genomic sequence (Collen et al. 2013). Gametophytes are composed primarily of kappa- and iota-carrageenan $(\sim 70 \%$ and $20 \%)$ and the biological precursors mu- and nucarrageenan ( $\sim 8 \%$ and $2 \%)$ whereas tetrasporophytes have a 
majority of lambda-carrageenan in their CWs (Chopin et al. 1987; Tasende et al. 2012). These different carrageenans lend different rheological properties to the $\mathrm{CW}$ of $C$. crispus (Carrington et al. 2001). Industry exploits kappa- and iotacarrageenan for their gel forming properties, while lambdacarrageenan is used mainly as a thickening agent (Campo et al. 2009).

While a biosynthesis pathway for the carrageenan polysaccharide has been proposed by Craigie and elaborated on by Collen et al. (Craigie \& Wong 1978; Collén et al. 2014), it remains mainly hypothetical. The carrageenan matrix polysaccharides are thought to be produced by the secretory pathway of the cell, in the Golgi apparatus, where GTs form the linear alternating $\alpha-1,3$ and $\beta-1,4$ linkages of the neutral galactan. After polymerization of the polysaccharide chain, sulfurylation is proposed to occur in the Golgi apparatus by specific STs. This carrageenan precursor is then believed to be transported to the $\mathrm{CW}$. Here, it is further modified to form the 3,6-anhydro-D-galactose molecule by galactose-6sulfurylases (Wong \& Craigie 1978; Genicot-Joncour et al. 2009). This remains the only step in algal carrageenan biosynthesis that has been biochemically demonstrated to date.

Alternating $\beta-1,4$ and $\alpha-1,3$-linkages make up the polymer backbone of carrageenan and this suggests a coordinated activity of at least two GTs. While a neutral galactan is proposed to be the initial precursor for carrageenan, there is no evidence that this polysaccharide exists in red algae. Strikingly, all the galactans isolated from red algae contain either $\alpha$-1,3-linked 3,6-anhydrogalactose or $\alpha$-1,3-linked galactose-6-sulfate (the precursor for 3,6-anhydrogalactose). This suggests that the presence of a 6 -sulfate group on the $\alpha-1,3$-linked galactose residues is systematic in the precursor galactan chain (before the action of the galactose6-sulfurylases). Such a systematic sulfurylation of the O6 position seems unlikely in the scenario of the synthesis of a neutral precursor galactan which would require later sulfurylations by endo-, random-acting sulfotransferases (original Wong and Craigie scenario). While neutral $\beta$-1,4-linked galactose has been identified in carrageenan (Greer \& Yaphe 1984; Chiovitti et al. 2008) there has been no experimental substantiation for the presence of the neutral $\alpha$-1,3-linked galactose molecule. Based on this (lack of) evidence we propose here two alternative pathways for carrageenan biosynthesis. The first scenario is, rather than initially producing a neutral galactan polymer, a 6-sulfated polysaccharide forms the precursor galactan chain (Fig. 5, pathway 1). Thus, an activated D-galactose-6-sulfate molecule is linked $\alpha-1,3$ into the growing mixed-link galactan chain by a specific GT. The alternating $\beta$-1,4-linked $\mathrm{D}$-galactose residue is incorporated by a different GT. The second scenario (Figure 5, pathway 2) is a revised version of the pathway proposed by Craigie \& Wong: a neutral galactan chain is synthesized by specific $\alpha-1,3 / \beta-1,4$ GTs and, simultaneously, a highly processive ST adds the C6-sulfate group to form D-galactose-6-sulfate.
Interestingly, the genome of C. crispus contains several genes encoding proteins which share sequence homology to animal GT7s involved in the biosynthesis of chondroitin sulfate, a glycosaminoglycan (GAG). The animal GT7s form the $\beta$-1,4-linkage between $N$-acetyl-D-galactosamine and D-glucuronic acid during chondroitin sulfate synthesis (Yada et al. 2003). GT14, GT47, and GT64 members have likewise been identified as being closely related to animal GTs which are implicated in the synthesis of the GAG heparan sulfate (Collen et al. 2013). Animal GT64 members form the $\alpha-1,4$ linkages with $N$-acetyl-D-glucosamine on the growing heparan chain (Pedersen et al. 2003). C. crispus also possesses two GT8 enzymes more closely related to GTs involved in hemicellulose and pectin biosynthesis in plants. The relationship to sulfated GAG biosynthesis in animals and $\mathrm{CW}$ biosynthesis in plants strongly suggests these GTs from $C$. crispus are involved in the synthesis of the sulfated carrageenan polymer (Collen et al. 2013). Furthermore, nine genes encoding carbohydrate STs were identified that are related to vertebrate STs involved in sulfurylation of proteinand lipid-linked oligosaccharides (Ong et al. 1998), $N$ - and $O$-linked glycans (Hiraoka et al. 2001), the glycoprotein carbonic anhydrase VI (Kang et al. 2001) and the matrix GAGs (Evers et al. 2001; Mikami et al. 2003). This fascinating relationship between sulfated algal $\mathrm{CW}$ polysaccharide biosynthesis and the synthesis of sulfated animal sugars, in particular the GAGs, suggests an ancient eukaryotic origin for these pathways.

C. crispus possesses 12 genes encoding galactose6-sulfurylases (Collen et al. 2013). CHC_T00008516001 and CHC_T00009416001 are identical to the genes of the D-galactose-2,6-sulfurylases I and II previously characterized by Genicot and coworkers (Genicot-Joncour et al. 2009). While there is only one D-galactose-2,6-sulfurylase I, C. crispus contains 11 paralogous genes encoding D-galactose-2,6-sulfurylases II (with sequence identities ranging from $55 \%$ to $99 \%$, using $\mathrm{CHC}_{\text {C }} \mathrm{T} 00009416001$ as a reference sequence). These genes represent a rare case of a multigenic family found in the C. crispus genome. The enzyme responsible for the conversion of precursor mucarrabiose to kappa-carrabiose, which was detected by Wong and Craigie (Wong \& Craigie 1978), is expected to be encoded by one of these paralogous D-galactose-2,6sulfurylases II (Collen et al. 2013). Furthermore, one of the as yet uncharacterized D-galactose-6-sulfurylases is likely responsible for the conversion of lambda carrageenan to theta carrageenan (Fig. 5).

Unexpectedly, no sulfatases, predicted to be necessary for $\mathrm{CW}$ remodeling, were identified in the C. crispus genome. However, C. crispus produces three GHs related to bacterial kappa-carrageenases (GH16s) (Michel et al. 2001). These enzymes are excellent candidates for involvement in CW remodeling (Supplementary Table 1). 


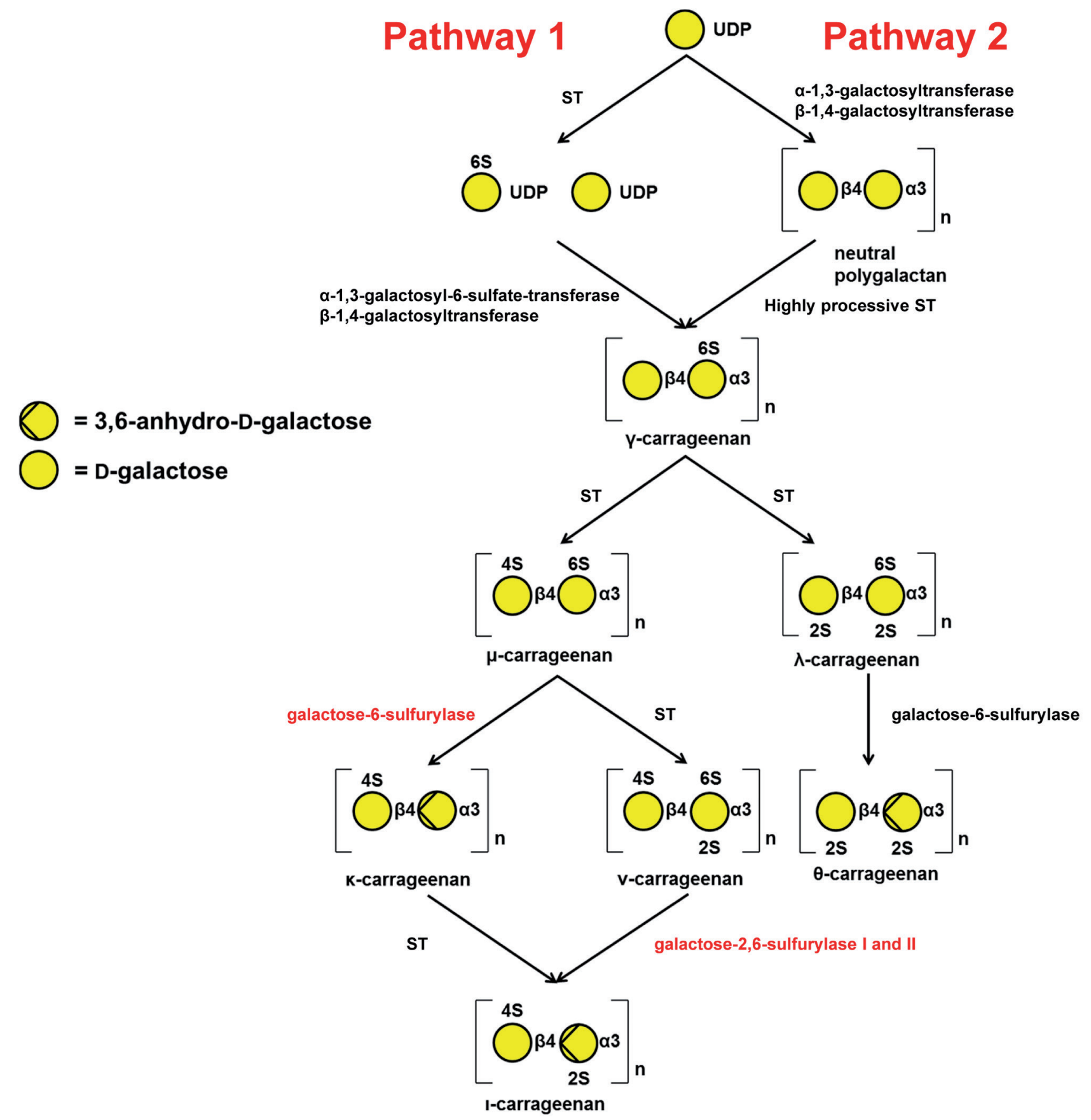

Fig. 5. Proposed carrageenan biosynthesis pathways. Pathway 1. D-galactose-6-sulfate-UDP is first synthesized from D-galactoseUDP. D-galactose-6-sulfate and D-galactose are incorporated into the growing carrageenan precursor in alternating $\alpha-1,3$ and $\alpha-1,4-$ linkages by specific GTs. Pathway 2. D-galactose is incorporated into the growing carrageenan precursor in alternating $\alpha-1,3$ and $\alpha-1,4$-linkages by specific GTs. A highly processive ST follows forming the D-galactose-6-sulfate moiety. All further steps in the pathway are as previously described (Wong \& Craigie 1978; Collén et al. 2014). The enzymes highlighted in red have been characterized experimentally (Craigie \& Wong 1978; Wong \& Craigie 1978; Genicot-Joncour et al. 2009). 


\section{Brown algae}

The brown algal $\mathrm{CW}$ is composed mainly of the anionic polysaccharides alginate and FCSPs, though cellulose is present in lesser amounts (Kloareg \& Quatrano 1988; Michel et al. 2010; Popper et al. 2011). A revised model of the CWs of Fucales has been recently proposed which highlights the interactions of these different polymers (Deniaud-Bouet et al. 2014). Moreover, brown algae can synthesize different sets of FCSPs depending on the species and life-stage (Anastyuk et al. 2012a). Homopolymeric sulfated fucans have repeating units of $\alpha$-L-fucose moieties linked either $\alpha-1,3$ or alternating $\alpha-1,3 / \alpha-1,4$ (Berteau \& Mulloy 2003; Chattopadhyay et al. 2010; Jiao et al. 2011) and the polymers may be branched with galactose (Rocha et al. 2005; Bilan et al. 2013; Anastyuk et al. 2014), xylose (Bilan et al. 2014) or fucose residues (Chevolot et al. 1999; Pereira et al. 1999; Pomin \& Mourao 2008). Sulfurylations may be found on the $\mathrm{O} 4$ or $\mathrm{O} 2$ and less often on the $\mathrm{O} 3$ position of fucose depending on the brown alga (Ale et al. 2011) and acetylations may also be present (Chizhov et al. 1999; Pomin \& Mourao 2008). Fucan structures with both $\alpha-1,3 / \alpha-1,4$-linkages are found in Fucus vesiculosus, Pelvetia canaliculata (Colin et al. 2006; Descamps et al. 2006) and Silvetia babingtonii (Anastyuk et al. 2012b), while linear $\alpha$-1,3-linkages are found in Chorda filum and Himanthalia elongata (Fig. 6) (Nishino et al. 1991; Chevolot et al. 1999; Chizhov et al. 1999; Pereira et al. 1999; Pomin \& Mourao 2008; DeniaudBouet et al. 2014). Although $F$. vesiculosus and $H$. elongata are both Fucales, they do not share the same fucan backbone structure.

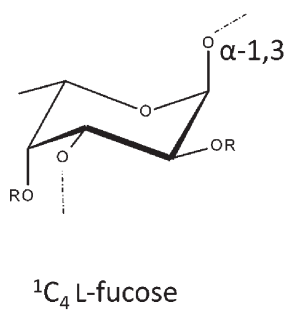

$\alpha-1,3$-linkage

$\mathrm{R}=\mathrm{H}, \mathrm{SO}_{3}{ }^{-}$

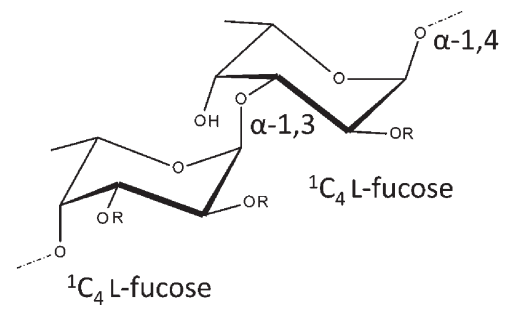

\section{$\alpha-1,3 / \alpha-1,4-$ linkage}

Fig. 6. Examples of two homo-fucan motifs. The first is the $\alpha-1,3-$ linked L-fucose moiety such as found in C. filum (Laminariales) and $H$. elongata (Fucales). The second, such as found in $F$. vesiculosus (Fucales), is $\alpha-1,3 / \alpha-1,4$-linked L-fucose which also has neutral fucose branch points.
FCSPs cover a broader range of complex fucose-rich polysaccharides other than those having a homofucan backbone only; these are the heteropolymeric FCSPs (formerly fucoidan). The chemical structures currently described include polymers having a uronic acid backbone, most commonly designated as mannuronic acid (initially ascophyllans or sulfated xylofucoglucuronan) (Medcalf \& Larsen 1977; Kloareg et al. 1986; Kloareg \& Quatrano 1988; Leite et al. 1998; Queiroz et al. 2008), a galactan backbone (sulfated fucogalactans, initially sargassans or glycuronofucoglycans) (Duarte et al. 2001; Bilan et al. 2010; Ale et al. 2011), a backbone made of alternating mannose and glucuronic acid residues (sulfated fucoglucuronomannan) (Bilan et al. 2010; Croci et al. 2011) or of galactose and mannose residues (Duarte et al. 2001; Bilan et al. 2010). It is evident that additional structures may be present but are so far undescribed. Thus, while at times the literature on brown algal FCSPs is challenging to interpret, it is clear that there is no consistent basic structure of the FCSPs and that they are highly heterogeneous and structurally variable polymers which may differ greatly even between species of brown algae.

The genome sequencing of the marine filamentous brown alga $E$. siliculosus has provided insight into sulfated carbohydrate metabolism of brown algae (Cock et al. 2010; Michel et al. 2010). No fucan modifying enzymes from brown algae have been functionally characterized to date; however, it is hypothesized that the sulfated homofucans are polymerized as neutral polysaccharides by one or more fucosyltransferases followed by sulfurylation by specific STs (Fig. 7). With analogy to plants, animals and most bacteria, GDP-fucose is likely produced de novo from fucose and GDP-mannose. Predicted enzymes, which are highly similar in amino acid sequence to animal and fungal enzymes, have been identified from the genome sequence as likely being involved in the production of GDP-fucose de novo (Michel et al. 2010), particularly GDP-mannose 4,6-dehydratase, GDP-L-fucose synthetase (a bifunctional epimerase/reductase), and via an alternative salvage pathway with the enzymes L-fucokinase and L-GDP-fucose pyrophosphorylase. (Becker \& Lowe 2003; Michel et al. 2010). The incorporation of GDP-fucose into a neutral fucan polysaccharide precursor is speculative, though neutral fucose residues have been identified in the brown algal FCSPs. Thus, a neutral fucan chain may be synthesized by an $\alpha-1,3$-fucosyltransferase alone or using both an $\alpha-1,3$-fucosyltransferase and an $\alpha-1,4$-fucosyltransferase. Following chain synthesis, sulfate groups are likely incorporated by specific STs. Several fucosyltransferase GTs from families GT10, GT23 and GT65 were identified which may be implicated in elongation of the fucan chain, though in other eukaryotes these enzymes are characterized as being involved in protein glycosylation. Of course this is an extremely simplified view of FCSP biosynthesis as the heteropolymer is extraordinarily complex. A key finding is the presence of seven carbohydrate ST genes in the E. siliculosus genome (Michel et al. 2010). These carbohydrate STs are 


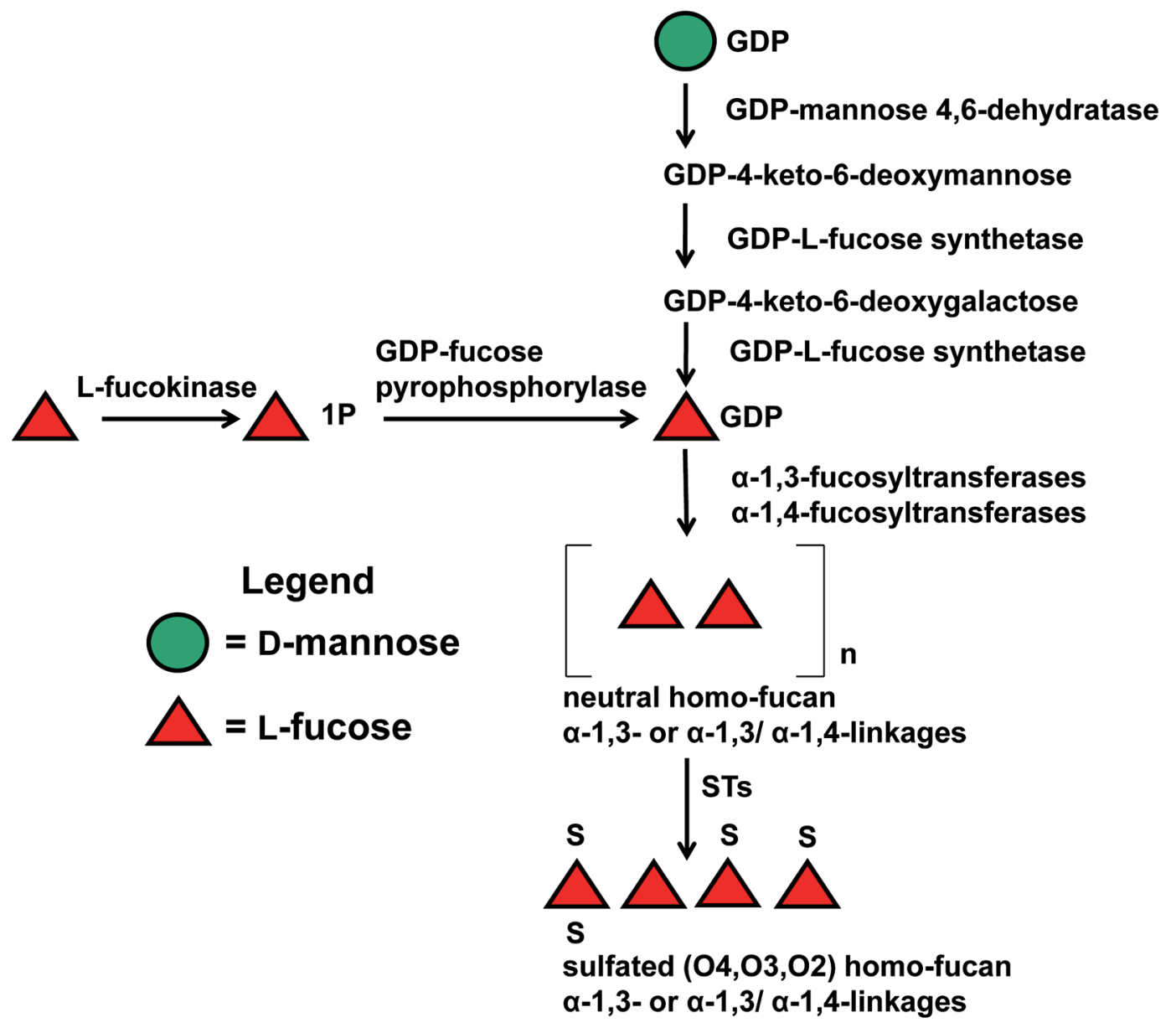

Fig. 7. Proposed homofucan biosynthesis pathway.

homologous to the animal STs involved in the biosynthesis of the GAG heparan sulfate and are thus excellent candidates for $\mathrm{CW}$ sulfating enzymes. Their paralogous nature may reflect positional differences in enzyme specificity along the fucan backbone.

Up to now only one fucanase gene has been cloned, from the marine bacterium Mariniflexile fucanivorans (Colin et al. 2006), defining family 107 of the GHs. However, no GH107 gene has been found in the E. siliculosus genome (Michel et al. 2010) and the involvement of such enzymatic activity in the modification or recycling of FCSP is uncertain in brown algae. Nonetheless, nine sulfatases related to animal GAG sulfatases have been also identified in the E. siliculosus genome. These sulfatases are probably implicated in the remodeling of the sulfated $\mathrm{CW}$ fucans and are dependent on a catalytic $\mathrm{C}_{\alpha}$-formylglycine residue (Schmidt et al. 1995). Additionally, two proteins were identified that are similar to human formylglycine-generating enzymes (Dierks et al. 2003) which are essential for post-translationally modifying the catalytic cysteine of the formylglycine-sulfatases.

\section{Conclusion}

All marine seaweeds display sulfated polysaccharides as CW components. In contrast land plants do not produce sulfated polysaccharides. The genomic analyses of the carbohydrate metabolism of the brown alga E. siliculosus (Michel et al. 2010) and of the red alga C. crispus (Collen et al. 2013) have revealed that animals and both red and brown algae possess homologous carbohydrate STs which are involved in the biosynthesis of sulfated polysaccharides. This indicates that the synthesis of sulfated polysaccharides is an ancient eukaryotic capacity. The genome sequencing of green seaweed would be essential to determine if their carbohydrate STs are also conserved. In contrast, available genomes of land plants do not include carbohydrate STs and sulfatases. Sulfate ions are abundant in seawater but rare in terrestrial environment. Thus, land plants have most likely lost these genes as an adaptation to terrestrial constraints (Michel et al. 2010; Collen et al. 2013). Fascinatingly, marine angiosperms, which have returned to the ocean by diverging from 
a terrestrial plant ancestor, also contain sulfated polysaccharides in their CWs (Maeda et al. 1966; Aquino et al. 2005; Aquino et al. 2011). This suggests that the sulfurylation of CW polysaccharides was a needed step for angiosperms to readapt to the marine environment. The mechanism of this regain of function remains an evolutionary mystery and the genome sequencing of a marine angiosperm is also a much awaited event.

Although the genome sequencing of E. siliculosus and of C. crispus have provided much needed molecular insights into the biosynthesis of sulfated polysaccharides in macroalgae this is only the beginning of the story. Indeed, a tremendous amount of work is now in front of us to experimentally validate and complete the metabolic pathways presented herein.

Acknowledgements: EFB was funded by a postdoctoral fellowship supported by the Region Bretagne through the program 'Algevol' with reference SAD_Obex_EMBRC 12010152. CH and GM are grateful for support by the French Centre National de Recherches Scientifiques. This work also benefited from the support of the French Government through the National Research Agency with regard to the IDEALG investment expenditure program with reference ANR-10-BTBR-04.

\section{References}

Ale, M.T., Mikkelsen, J.D. \& Meyer, A.S. (2011): Important determinants for fucoidan bioactivity: a critical review of structurefunction relations and extraction methods for fucose-containing sulfated polysaccharides from brown seaweeds. - Mar. Drugs 9: 2106-2130.

Anastyuk, S.D., Imbs, T.I., Dmitrenok, P.S. \& Zvyagintseva, T.N. (2014): Rapid mass spectrometric analysis of a novel fucoidan, extracted from the brown alga Coccophora langsdorfii. - Sci. World J. 2014: 972450.

Anastyuk, S.D., Imbs, T.I., Shevchenko, N.M., Dmitrenok, P.S., Zvyagintseva, T.N. (2012a): ESIMS analysis of fucoidan preparations from Costaria costata, extracted from alga at different life-stages. - Carbohydr. Polym. 90: 993-1002.

Anastyuk, S.D., Shevchenko, N.M., Dmitrenok, P.S., Zvyagintseva, T.N. (2012b): Structural similarities of fucoidans from brown algae Silvetia babingtonii and Fucus evanescens, determined by tandem MALDI-TOF mass spectrometry. - Carbohydr. Res. 358: 78-81.

Anderson, N.S. \& Rees, D.A. (1965): Porphyran - a Polysaccharide with a Masked Repeating Structure. - J. Chem. Soc.: 5880.

Andrade, L.R., Leal, R.N., Noseda, M., Duarte, M.E.R., Pereira, M.S., Mourao, P.a.S., Farina, M. \& Amado, G.M. (2010): Brown algae overproduce cell wall polysaccharides as a protection mechanism against the heavy metal toxicity. - Mar. Pollut. Bull. 60: $1482-1488$.

Aquino, R.S., Grativol, C., Mourao, P.A. (2011): Rising from the sea: correlations between sulfated polysaccharides and salinity in plants. - PLoS ONE 6: e18862.

Aquino, R.S., Landeira-Fernandez, A.M., Valente, A.P., Andrade, L.R. \& Mourao, P.A. (2005): Occurrence of sulfated galactans in marine angiosperms: evolutionary implications. - Glycobiol. 15: $11-20$.

Arad, S. \& Levy-Ontman, O. (2010): Red microalgal cell-wall polysaccharides: biotechnological aspects. - Curr. Opin. Biotech. 21: 358-364.

Baldauf, S.L. (2008): An overview of the phylogeny and diversity of eukaryotes. - J. Syst. Evol. 46: 263-273.

Becker, D.J. \& Lowe, J.B. (2003): Fucose: biosynthesis and biological function in mammals. - Glycobiol. 13: 41R-53R.

Berteau, O. \& Mulloy, B. (2003): Sulfated fucans, fresh perspectives: structures, functions, and biological properties of sulfated fucans and an overview of enzymes active toward this class of polysaccharide. - Glycobiol. 13: 29R-40R.

Bilan, M.I., Grachev, A.A., Shashkov, A.S., Kelly, M., Sanderson, C.J., Nifantiev, N.E. \& Usov, A.I. (2010): Further studies on the composition and structure of a fucoidan preparation from the brown alga Saccharina latissima. - Carbohydr. Res. 345: 2038-2047.

Bilan, M.I., Grachev, A.A., Shashkov, A.S., Thuy, T.T., Van, T.T., Ly, B.M., Nifantiev, N.E. \& Usov, A.I. (2013): Preliminary investigation of a highly sulfated galactofucan fraction isolated from the brown alga Sargassum polycystum. - Carbohydr. Res. 377: 48-57.

Bilan, M.I., Shashkov, A.S. \& Usov, A.I. (2014): Structure of a sulfated xylofucan from the brown alga Punctaria plantaginea. Carbohydr. Res. 393: 1-8.

Bilan, M.I., Vinogradova, E.V., Shashkov, A.S. \& Usov, A.I. (2006): Isolation and preliminary characterization of a highly pyruvylated galactan sulfate from Codium yezoense (Bryopsidales, Chlorophyta). - Bot. Mar. 49: 259-262.

Bilan, M.I., Vinogradova, E.V., Shashkov, A.S. \& Usoy, A.I. (2007): Structure of a highly pyruvylated galactan sulfate from the Pacific green alga Codium yezoense (Bryopsidales, Chlorophyta). Carbohydr. Res. 342: 586-596.

Bouhlal, R., Haslin, C., Chermann, J.C., Colliec-Jouault, S., Sinquin, C., Simon, G., Cerantola, S., Riadi, H. \& Bourgougnon, N. (2011): Antiviral Activities of Sulfated Polysaccharides Isolated from Sphaerococcus coronopifolius (Rhodophytha, Gigartinales) and Boergeseniella thuyoides (Rhodophyta, Ceramiales). - Mar. Drugs 9: 1187-1209.

Brading, J.W.E., Georgplant, M.M.T. \& Hardy, D.M. (1954): The Polysaccharide from the Alga Ulva lactuca - Purification, Hydrolysis, and Methylation of the Polysaccharide. - J. Chem. Soc.: 319-324.

Brownlee, C. (2002): Role of the extracellular matrix in cell-cell signalling: paracrine paradigms. - Curr. Opin. Plant Biol. 5: 396-401.

Campo, V.L., Kawano, D.F., Da Silva, D.B., Carvalho, I. (2009): Carrageenans: Biological properties, chemical modifications and structural analysis - A review. - Carbohyd. Polym. 77: 167-180.

Cantarel, B.L., Coutinho, P.M., Rancurel, C., Bernard, T., Lombard, V. \& Henrissat, B. (2008): The Carbohydrate-Active EnZymes database (CAZy): an expert resource for Glycogenomics. Nucleic Acids Res. 37: D233-D2338.

Carrington, E., Grace, S.P. \& Chopin, T. (2001): Life history phases and the biomechanical properties of the red alga Chondrus crispus (Rhodophyta). - J. Phycol. 37: 699-704.

Cassolato, J.E.F., Noseda, M.D., Pujolb, C.A., Pellizzaric, F.M., Damonte, E.B. \& Duarte, M.E.R. (2008): Chemical structure and antiviral activity of the sulfated heterorhamnan isolated 
from the green seaweed Gayralia oxysperma. - Carbohydr. Res. 343: 3085-3095.

Chattopadhyay, K., Adhikari, U., Lerouge, P. \& Ray, B. (2007): Polysaccharides from Caulerpa racemosa: Purification and structural features. - Carbohyd. Polym. 68: 407-415.

Chattopadhyay, N., Ghosh, T., Sinha, S., Chattopadhyay, K., Karmakar, P. \& Ray, B. (2010): Polysaccharides from Turbinaria conoides: Structural features and antioxidant capacity. - Food Chem. 118: 823-829.

Chen, B.L., You, W.L., Huang, J., Yu, Y. \& Chen, W.P. (2010): Isolation and antioxidant property of the extracellular polysaccharide from Rhodella reticulata. - World J. Microb. Biot. 26: 833-840.

Chevolot, L., Foucault, A., Chaubet, F., Kervarec, N., Sinquin, C., Fisher, A.M. \& Boisson-Vidal, C. (1999): Further data on the structure of brown seaweed fucans: relationships with anticoagulant activity. - Carbohydr. Res. 319: 154-165.

Chiovitti, A., Kraft, G.T., Bacic, A., Craik, D.J. \& Liao, M.L. (2008): Kappa-/beta-carrageenans from Australian red algae of the Acrotylaceae (Gigartinales, Rhodophyta). - Phycologia 47: 35-40.

Chizhov, A.O., Dell, A., Morris, H.R., Haslam, S.M., Mcdowell, R.A., Shashkov, A.S., Nifant'ev, N.E., Khatuntseva, E.A. \& Usov, A.I. (1999): A study of fucoidan from the brown seaweed Chorda filum. - Carbohydr. Res. 320: 108-119.

Chopin, T., Bodeaubellion, C., Floch, J.Y., Guittet, E. \& Lallemand, J.Y. (1987): Seasonal Study of Carrageenan Structures from Female Gametophytes of Chondrus crispus Stackhouse (Rhodophyta). - Hydrobiologia 151: 535-539.

Ciancia, M., Alberghina, J., Arata, P.X., Benavides, H., Leliaert, F., Verbruggen, H. \& Estevez, J.M. (2012): Characterization of Cell Wall Polysaccharides of the Coencocytic Green Seaweed Bryopsis Plumosa (Bryopsidaceae, Chlorophyta) from the Argentine Coast. - J. Phycol. 48: 326-335.

Ciancia, M., Matulewicz, M.C. \& Cerezo, A.S. (1993): L-Galactose Containing Galactans from the Carrageenophyte Gigartina skottsbergii. - Phytochemistry 34: 1541-1543.

Ciancia, M., Matulewicz, M.C. \& Cerezo, A.S. (1997): A L-galactose-containing carrageenan from cystocarpic Gigartina skottsbergii. - Phytochemistry 45: 1009-1013.

Ciancia, M., Quintana, I., Vizcarguenaga, M.I., Kasulin, L., De Dios, A., Estevez, J.M. \& Cerezo, A.S. (2007): Polysaccharides from the green seaweeds Codium fragile and C. vermilara with controversial effects on hemostasis. - Int. J. Biol. Macromol. 41: 641-649.

Cock, J.M., Sterck, L., Rouze, P., Scornet, D., Allen, A.E., Amoutzias, G., Anthouard, V., Artiguenave, F., Aury, J.M., Badger, J.H., Beszteri, B., Billiau, K., Bonnet, E., Bothwell, J.H., Bowler, C., Boyen, C., Brownlee, C., Carrano, C.J., Charrier, B., Cho, G.Y., Coelho, S.M., Collen, J., Corre, E., Da Silva, C., Delage, L., Delaroque, N., Dittami, S.M., Doulbeau, S., Elias, M., Farnham, G., Gachon, C.M., Gschloessl, B., Heesch, S., Jabbari, K., Jubin, C., Kawai, H., Kimura, K., Kloareg, B., Kupper, F.C., Lang, D., Le Bail, A., Leblanc, C., Lerouge, P., Lohr, M., Lopez, P.J., Martens, C., Maumus, F., Michel, G., Miranda-Saavedra, D., Morales, J., Moreau, H., Motomura, T., Nagasato, C., Napoli, C.A., Nelson, D.R., Nyvall-Collen, P., Peters, A.F., Pommier, C., Potin, P., Poulain, J., Quesneville, H., Read, B., Rensing, S.A., Ritter, A., Rousvoal, S., Samanta, M., Samson, G., Schroeder, D.C., Segurens, B., Strittmatter, M., Tonon, T., Tregear, J.W., Valentin, K., Von
Dassow, P., Yamagishi, T., Van De Peer, Y. \& Wincker, P. (2010): The Ectocarpus genome and the independent evolution of multicellularity in brown algae. - Nature 465: 617-621.

Colin, S., Deniaud, E., Jam, M., Descamps, V., Chevolot, Y., Kervarec, N., Yvin, J.C., Barbeyron, T., Michel, G. \& Kloareg, B. (2006): Cloning and biochemical characterization of the fucanase FcnA: definition of a novel glycoside hydrolase family specific for sulfated fucans. - Glycobiol. 16: 1021-1032.

Collén, J., Cornish, M.L., Craigie, J., Ficko-Blean, E., Hervé, C., Krueger-Hadfield, S.A., Leblanc, C., Michel, G., Potin, P., Tonon, T. \& Boyen, C. (2014): Chondrus crispus - A Present and Historical Model Organism for Red Seaweeds. - In: Advances in Botanical Research 71: 53-89. Elsevier Ltd.

Collen, J., Porcel, B., Carre, W., Ball, S.G., Chaparro, C., Tonon, T., Barbeyron, T., Michel, G., Noel, B., Valentin, K., Elias, M., Artiguenave, F., Arun, A., Aury, J.M., Barbosa-Neto, J.F., Bothwell, J.H., Bouget, F.Y., Brillet, L., Cabello-Hurtado, F., Capella-Gutierrez, S., Charrier, B., Cladiere, L., Cock, J.M., Coelho, S.M., Colleoni, C., Czjzek, M., Da Silva, C., Delage, L., Denoeud, F., Deschamps, P., Dittami, S.M., Gabaldon, T., Gachon, C.M., Groisillier, A., Herve, C., Jabbari, K., Katinka, M., Kloareg, B., Kowalczyk, N., Labadie, K., Leblanc, C., Lopez, P.J., Mclachlan, D.H., Meslet-Cladiere, L., Moustafa, A., Nehr, Z., Nyvall Collen, P., Panaud, O., Partensky, F., Poulain, J., Rensing, S.A., Rousvoal, S., Samson, G., Symeonidi, A., Weissenbach, J., Zambounis, A., Wincker, P. \& Boyen, C. (2013): Genome structure and metabolic features in the red seaweed Chondrus crispus shed light on evolution of the Archaeplastida. - Proc. Natl. Acad. Sci. U.S.A. 110: 5247-5252.

Collen, P.N., Jeudy, A., Sassi, J.F., Groisillier, A., Czjzek, M., Coutinho, P.M. \& Helbert, W. (2014): A novel unsaturated betaglucuronyl hydrolase involved in ulvan degradation unveils the versatility of stereochemistry requirements in family GH105. J. Biol. Chem. 289: 6199-6211.

Correc, G., Hehemann, J.H., Czjzek, M. \& Helbert, W. (2011): Structural analysis of the degradation products of porphyran digested by Zobellia galactanivorans beta-porphyranase A. Carbohyd. Polym. 83: 277-283.

Craigie, J. \& Wong, K.F. (1978): Carrageenan Biosynthesis. - In: Proc Int Seaweed Symp, pp. 595-609.

Craigie, J.S. (1990): Biology of the Red Algae. Cambridge University Press, Cambridge, UK.

Croci, D.O., Cumashi, A., Ushakova, N.A., Preobrazhenskaya, M.E., Piccoli, A., Totani, L., Ustyuzhanina, N.E., Bilan, M.I., Usov, A.I., Grachev, A.A., Morozevich, G.E., Berman, A.E., Sanderson, C.J., Kelly, M., Di Gregorio, P., Rossi, C., Tinari, N., Iacobelli, S., Rabinovich, G.A. \& Nifantiev, N.E. (2011): Fucans, but not fucomannoglucuronans, determine the biological activities of sulfated polysaccharides from Laminaria saccharina brown seaweed. - PLoS ONE 6: e17283.

Deniaud-Bouet, E., Kervarec, N., Michel, G., Tonon, T., Kloareg, B. \& Herve, C. (2014): Chemical and enzymatic fractionation of cell walls from Fucales: insights into the structure of the extracellular matrix of brown algae. - Ann. Bot. 114: 1203-1216.

Deniaud, E., Quemener, B., Fleurence, J. \& Lahaye, M. (2003): Structural studies of the mix-linked beta-(1-->3)/beta-(1-->4)D-xylans from the cell wall of Palmaria palmata (Rhodophyta).Int. J. Biol. Macromol. 33: 9-18.

Descamps, V., Colin, S., Lahaye, M., Jam, M., Richard, C., Potin, P., Barbeyron, T., Yvin, J.C. \& Kloareg, B. (2006): Isolation and 
culture of a marine bacterium degrading the sulfated fucans from marine brown algae. - Mar. Biotechnol. (NY) 8: 27-39.

Dierks, T., Schmidt, B., Borissenko, L.V., Peng, J.H., Preusser, A., Mariappan, M. \& Von Figura, K. (2003): Multiple sulfatase deficiency is caused by mutations in the gene encoding the human C-alpha-formylglycine generating enzyme. - Cell 113: 435-444.

Domozych, D.S., Ciancia, M., Fangel, J.U., Mikkelsen, M.D., Ulvskov, P. \& Willats, W.G.T. (2012): The cell walls of green algae: a journey through evolution and diversity. - Front Plant. Sci. 3.

Duarte, M.E.R., Cardoso, M.A., Noseda, M.D. \& Cerezo, A.S. (2001): Structural studies on fucoidans from the brown seaweed Sargassum stenophyllum. - Carb. Res. 333: 281-293.

Errea, M.I. \& Matulewicz, M.C. (2003): Unusual structures in the polysaccharides from the red seaweed Pterocladiella capillacea (Gelidiaceae, Gelidiales). - Carb. Res. 338: 943-953.

Estevez, J.M., Ciancia, M. \& Cerezo, A.S. (2001): DL-galactan hybrids and agarans from gametophytes of the red seaweed Gymnogongrus torulosus. - Carb. Res. 331: 27-41.

Estevez, J.M., Ciancia, M., Cerezo, A.S. (2004): The system of galactans of the red seaweed, Kappaphycus alvarezii, with emphasis on its minor constituents. - Carb Res 339: 2575-2592.

Estevez, J.M., Fernandez, P.V., Kasulin, L., Dupree, P. \& Ciancia, M. (2009): Chemical and in situ characterization of macromolecular components of the cell walls from the green seaweed Codium fragile. - Glycobiol. 19: 212-228.

Evers, M.R., Xia, G.Q., Kang, H.G., Schachner, M. \& Baenziger, J.U. (2001): Molecular cloning and characterization of a dermatan-specific $\mathrm{N}$-acetylgalactosamine 4-O-sulfotransferase.J. Biol. Chem. 276: 36344-36353.

Farias, E.H., Pomin, V.H., Valente, A.P., Nader, H.B., Rocha, H.A. \& Mourao, P.A. (2008): A preponderantly 4-sulfated, 3-linked galactan from the green alga Codium isthmocladum. - Glycobiol 18: 250-259.

Fernandez, P.V., Arata, P.X. \& Ciancia, M. (2014): Polysaccharides from Codium Species: Chemical Structure and Biological Activity. Their Role as Components of the Cell Wall. - Adv. Bot. Res. 71: 253-278.

Fernandez, P.V., Quintana, I., Cerezo, A.S., Caramelo, J.J., PolFachin, L., Verli, H., Estevez, J.M. \& Ciancia, M. (2013): Anticoagulant activity of a unique sulfated pyranosic (1->3)-beta-L-arabinan through direct interaction with thrombin. - J. Biol. Chem. 288: 223-233.

Genicot-Joncour, S., Poinas, A., Richard, O., Potin, P., Rudolph, B., Kloareg, B. \& Helbert, W. (2009): The cyclization of the 3,6-anhydro-galactose ring of iota-carrageenan is catalyzed by two D-galactose-2,6-sulfurylases in the red alga Chondrus crispus. - Plant Physiol. 151: 1609-1616.

Ghosh, T., Pujol, C.A., Damonte, E.B., Sinha, S. \& Ray, B. (2009): Sulfated xylomannans from the red seaweed Sebdenia polydactyla: structural features, chemical modification and antiviral activity. - Antiviral chemistry \& chemotherapy 19: 235-242.

Greer, C.W. \& Yaphe, W. (1984): Characterization of Hybrid (Beta-Kappa-Gamma) Carrageenan from Eucheuma gelatinae Agardh, J. (Rhodophyta, Solieriaceae) Using Carrageenases, Infrared and C-13-Nuclear Magnetic-Resonance Spectroscopy.Bot. Mar. 27: 473-478.

Guibet, M., Boulenguer, P., Mazoyer, J., Kervarec, N., Antonopoulos, A. \& Lafosse, M., Helbert, W. (2008):
Composition and distribution of carrabiose moieties in hybrid kappa-/iota-carrageenans using carrageenases. Biomacromolecules 9: 408-415.

Hehemann, J.H., Boraston, A.B. \& Czjzek, M. (2014): A sweet new wave: structures and mechanisms of enzymes that digest polysaccharides from marine algae. - Curr. Opin. Struct. Biol. 28C: 77-86.

Hehemann, J.H., Correc, G., Barbeyron, T., Helbert, W., Czjzek, M. \& Michel, G. (2010): Transfer of carbohydrate-active enzymes from marine bacteria to Japanese gut microbiota. - Nature 464: 908-912.

Hiraoka, N., Misra, A., Belot, F., Hindsgaul, O. \& Fukuda, M. (2001): Molecular cloning and expression of two distinct human $\mathrm{N}$-acetylgalactosamine 4-O-sulfotransferases that transfer sulfate to GalNAc beta 1 -> 4GlcNAc beta $1->\mathrm{R}$ in both $\mathrm{N}$ - and O-glycans. - Glycobiol. 11: 495-504.

Jiao, G.L., Yu, G.L., Zhang, J.Z. \& Ewart, H.S. (2011): Chemical Structures and Bioactivities of Sulfated Polysaccharides from Marine Algae. - Mar. Drugs 9: 196-223.

Jol, C.N., Neiss, T.G., Penninkhof, B., Rudolph, B. \& De Ruiter', G.A. (1999): A novel high-performance anion-exchange chromatographic method for the analysis of carrageenans and agars containing 3,6-anhydrogalactose. - Anal. Biochem. 268: 213-222.

Kang, H.G., Evers, M.R., Xia, G.Q., Baenziger, U. \& Schachner, M. (2001): Molecular cloning and expression of an $\mathrm{N}$-acetylgalactosamine-4-O-sulfotransferase that transfers sulfate to terminal and non-terminal beta 1,4-linked N-acetylgalactosamine. - J. Biol. Chem. 276: 10861-10869.

Kloareg, B., Demarty, M. \& Mabeau, S. (1986): Polyanionic Characteristics of Purified Sulfated Homofucans from BrownAlgae. - Int. J. Biol. Macromol. 8: 380-386.

Kloareg, B. \& Quatrano, R.S. (1988): Structure of the Cell-Walls of Marine-Algae and Ecophysiological Functions of the Matrix Polysaccharides. - Oceanogr. Mar. Biol. 26: 259-315.

Knutsen, S.H., Myslabodski, D.E., Larsen, B. \& Usov, A.I. (1994): A Modified System of Nomenclature for Red Algal Galactans. Bot. Mar. 37: 163-169.

Lahaye, M. (1998): NMR spectroscopic characterisation of oligosaccharides from two Ulva rigida ulvan samples (Ulvales, Chlorophyta) degraded by a lyase. - Carb. Res. 314: 1-12.

Lahaye, M., Brunel, M. \& Bonnin, E. (1997): Fine chemical structure analysis of oligosaccharides produced by an ulvan-lyase degradation of the water-soluble cell-wall polysaccharides from Ulva sp, (Ulvales, Chlorophyta). - Carbohydr. Res. 304: 325-333.

Lahaye, M., Cimadevilla, E.a.C., Kuhlenkamp, R., Quemener, B., Lognone, V. \& Dion, P. (1999): Chemical composition and C-13 NMR spectroscopic characterisation of ulvans from Ulva (Ulvales, Chlorophyta). - J. Appl. Phycol. 11: 1-7.

Lahaye, M. \& Ray, B. (1996): Cell-wall polysaccharides from the marine green alga Ulva "rigida" (Ulvales, Chlorophyta) NMR analysis of ulvan oligosaccharides. - Carb. Res. 283: 161-173.

Lahaye, M. \& Robic, A. (2007): Structure and functional properties of ulvan, a polysaccharide from green seaweeds. Biomacromolecules 8: 1765-1774.

Lahaye, M., Rondeau-Mouro, C., Deniaud, E. \& Buleon, A. (2003): Solid-state 13C NMR spectroscopy studies of xylans in the cell wall of Palmaria palmata (L. Kuntze, Rhodophyta). Carbohydr. Res. 338: 1559-1569. 
Lahaye, M., Yaphe, W., Viet, M.T.P. \& Rochas, C. (1989): C-13-NM-R Spectroscopic Investigation of Methylated and Charged Agarose Oligosaccharides and Polysaccharides. - Carbohydr. Res. 190: 249-265.

Lawson, C.J. \& Rees, D.A. (1970): An enzyme for the metabolic control of polysaccharide conformation and function. - Nature 227: 392-393.

Lechat, H., Amat, M., Mazoyer, J., Buleon, A. \& Lahaye, M. (2000): Structure and distribution of glucomannan and sulfated glucan in the cell walls of the red alga Kappaphycus alvarezii (gigartinales, rhodophyta). - J. Phycol. 36: 891-902.

Leite, E.L., Medeiros, M.G.L., Rocha, H.a.O., Farias, G.G.M., Da Silva, L.F., Chavante, S.F., De Abreu, L.D., Dietrich, C.P. \& Nader, H.B. (1998): Structure and pharmacological activities of a sulfated xylofucoglucuronan from the alga Spatoglossum schroederi. - Plant Sci. 132: 215-228.

Love, J. \& Percival, E. (1964): Polysaccharides of Green Seaweed Codium Fragile.2. Water-Soluble Sulphated Polysaccharides. J. Chem. Soc.: 3338.

Maeda, M., Koshikawa, M., Nisizawa, K. \& Takano, K. (1966): Cell wall constituents, especially pectic substance of a marine phanerogam Zostera marina. - Bot. Mag. Tokyo 79: 422-426.

Martin, M., Portetelle, D., Michel, G. \& Vandenbol, M. (2014): Microorganisms living on macroalgae: diversity, interactions, and biotechnological applications. - Appl. Microbiol. Biotechnol. 98: 2917-2935.

Matsubara, K., Matsuura, Y., Hori, K. \& Miyazawa, K. (2000): An anticoagulant proteoglycan from the marine green alga, Codium pugniformis. - J. Appl. Phycol. 12: 9-14.

Medcalf, D.G. \& Larsen, B. (1977): Structural Studies on Ascophyllan and Fucose-Containing Complexes from Brown Alga Ascophyllum nodosum. - Carb. Res. 59: 539-546.

Michel, G., Chantalat, L., Duee, E., Barbeyron, T., Henrissat, B., Kloareg, B. \& Dideberg, O. (2001): The kappa-carrageenase of $P$. carrageenovora features a tunnel-shaped active site: a novel insight in the evolution of Clan-B glycoside hydrolases. Structure 9: 513-525.

Michel, G., Nyval-Collen, P., Barbeyron, T., Czjzek, M. \& Helbert, W. (2006): Bioconversion of red seaweed galactans: a focus on bacterial agarases and carrageenases. - Appl. Microbiol. Biotechnol. 71: 23-33.

Michel, G., Tonon, T., Scornet, D., Cock, J.M. \& Kloareg, B. (2010): The cell wall polysaccharide metabolism of the brown alga Ectocarpus siliculosus. Insights into the evolution of extracellular matrix polysaccharides in Eukaryotes. - New Phytol. 188: 82-97.

Mikami, T., Mizumoto, S., Kago, N., Kitagawa, H. \& Sugahara, K. (2003): Specificities of three distinct human chondroitin/derma$\tan \mathrm{N}$-acetylgalactosamine 4-O-sulfotransferases demonstrated using partially desulfated dermatan sulfate as an acceptor Implication of differential roles in dermatan sulfate biosynthesis. - J. Biol. Chem. 278: 36115-36127.

Navarro, D.A. \& Stortz, C.A. (2003): Determination of the configuration of 3,6-anhydrogalactose and cyclizable alpha-galactose 6-sulfate units in red seaweed galactans. - Carbohydr. Res. 338: 2111-2118.

Nishino, T., Aizu, Y. \& Nagumo, T. (1991): Antithrombin activity of a fucan sulfate from the brown seaweed Ecklonia kurome. Thromb. Res. 62: 765-773.

Ong, E., Yeh, J.C., Ding, Y.L., Hindsgaul, O. \& Fukuda, M. (1998): Expression cloning of a human sulfotransferase that directs the synthesis of the HNK-1 glycan on the neural cell adhesion molecule and glycolipids. - J. Biol. Chem. 273: 5190-5195.

Pedersen, L.C., Dong, J., Taniguchi, F., Kitagawa, H., Krahn, J.M., Pedersen, L.G., Sugahara, K., Negishi, M. (2003): Crystal structure of an alpha 1,4-N-acetylhexosaminyltransferase (EXTL2), a member of the exostosin gene family involved in heparan sulfate biosynthesis. - J. Biol. Chem. 278: 14420-14428.

Percival, E. \& Wold, J.K. (1963): Acid Polysaccharide from Green Seaweed Ulva Lactuca 2. Site of Ester Sulphate. - J. Chem. Soc.: 5459.

Pereira, M.S., Mulloy, B. \& Mourao, P.A. (1999): Structure and anticoagulant activity of sulfated fucans. Comparison between the regular, repetitive, and linear fucans from echinoderms with the more heterogeneous and branched polymers from brown algae. - J. Biol. Chem. 274: 7656-7667.

Pomin, V.H. \& Mourao, P.A. (2008): Structure, biology, evolution, and medical importance of sulfated fucans and galactans. Glycobiol. 18: 1016-1027.

Popper, Z.A., Michel, G., Herve, C., Domozych, D.S., Willats, W.G., Tuohy, M.G., Kloareg, B. \& Stengel, D.B. (2011): Evolution and diversity of plant cell walls: from algae to flowering plants. - Ann. Rev. Plant Biol. 62: 567-590.

Queiroz, K.C.S., Medeiros, V.P., Queiroz, L.S., Abreu, L.R.D., Rocha, H.a.O., Ferreira, C.V., Juca, M.B., Aoyama, H. \& Leite, E.L. (2008): Inhibition of reverse transcriptase activity of HIV by polysaccharides of brown algae. - Biomed. Pharmacother 62: 303-307.

Rees, D.A. (1961): Enzymic synthesis of 3:6-anhydro-L-galactose within porphyran from 1-galactose 6-sulphate units. - Biochem. J. 81: 347-352.

Rees, D.A. (1969): Structure, conformation, and mechanism in the formation of polysaccharide gels and networks. - Adv. Carbohydr. Chem. Biochem. 24: 267-332.

Reyes-Prieto, A., Weber, A.P. \& Bhattacharya, D. (2007): The origin and establishment of the plastid in algae and plants. - Ann. Rev. Genet. 41: 147-168.

Rocha, H.a.O., Moraes, F.A., Trindade, E.S., Franco, C.R.C., Torquato, R.J.S., Veiga, S.S., Valente, A.P., Mourao, P.a.S., Leite, E.L., Nader, H.B. \& Dietrich, C.P. (2005): Structural and hemostatic activities of a sulfated galactofucan from the brown alga Spatoglossum schroederi - An ideal antithrombotic agent? - J. Biol. Chem. 280: 41278-41288.

Schmidt, B., Selmer, T., Ingendoh, A. \& Vonfigura, K. (1995): A Novel Amino-Acid Modification in Sulfatases That Is Defective in Multiple Sulfatase Deficiency. - Cell 82: 271-278.

Silchenko, A.S., Kusaykin, M.I., Kurilenko, V.V., Zakharenko, A.M., Isakov, V.V., Zaporozhets, T.S., Gazha, A.K. \& Zvyagintseva, T.N. (2013): Hydrolysis of Fucoidan by Fucoidanase Isolated from the Marine Bacterium, Formosa algae. - Mar. Drugs 11: 2413-2430.

Stortz, C.A., Cases, M.R. \& Cerezo, A.S. (1997): The system of agaroids and carrageenans from the soluble fraction of the tetrasporic stage of the red seaweed Iridaea undulosa. - Carbohyd. Polym. 34: 61-65.

Takano, R., Shiomoto, K., Kamei, K., Hara, S. \& Hirase, S. (2003): Occurrence of carrageenan structure in an agar from the red seaweed Digenea simplex (Wulfen) C. agardh (Rhodomelaceae, Ceramiales) with a short review of carrageenan-agarocolloid hybrid in the florideophycidae. - Bot. Mar. 46: 142-150.

Takano, R., Yokoi, T., Kamei, K., Hara, S. \& Hirase, S. (1999): Coexistence of agaroid and carrageenan structures in a 
polysaccharide from the red seaweed Rhodomela larix (Turner) C. Agardh. - Bot. Mar. 42: 183-188.

Tannin-Spitz, T., Bergman, M., Van-Moppes, D., Grossman, S. \& Arad, S. (2005): Antioxidant activity of the polysaccharide of the red microalga Porphyridium sp. - J. Appl. Phycol. 17: $215-222$.

Tasende, M.G., Cid, M. \& Fraga, M.I. (2012): Spatial and temporal variations of Chondrus crispus (Gigartinaceae, Rhodophyta) carrageenan content in natural populations from Galicia (NW Spain). - J. Appl. Phycol. 24: 941-951.

Ucko, M., Cohen, E., Gordin, H. \& Arad, S.M. (1989): Relationship between the Unicellular Red Alga Porphyridium Sp. and Its Predator, the Dinoflagellate Gymnodinium Sp. - Appl. Environ. Microbiol. 55: 2990-2994.

Uehara, T., Takeshita, M. \& Maeda, M. (1992): Studies on Anticoagulant-Active Arabinan Sulfates from the Green-Alga, Codium latum. - Carb. Res. 235: 309-311.

Van De Velde, F. (2008): Structure and function of hybrid carrageenans. - Food Hydrocolloids 22: 727-734.

Van De Velde, F., Knutsen, S.H., Usov, A.I., Rollema, H.S. \& Cerezo, A.S. (2002): H-1 and C-13 high resolution NMR spectroscopy of carrageenans: application in research and industry.Trends Food Sci. Tech. 13: 73.
Viana, A.G., Noseda, M.D., Goncalves, A.G., Duarte, M.E., Yokoya, N., Matulewicz, M.C. \& Cerezo, A.S. (2011): betaD-(1-->4), beta-D-(1-->3) 'mixed linkage' xylans from red seaweeds of the order Nemaliales and Palmariales. - Carbohydr. Res. 346: 1023-1028.

Wong, K.F. \& Craigie, J.S. (1978): Sulfohydrolase Activity and Carrageenan Biosynthesis in Chondrus crispus (Rhodophyceae).Plant Physiol. 61: 663-666.

Yada, T., Sato, T., Kaseyama, H., Gotoh, M., Iwasaki, H., Kikuchi, N., Kwon, Y.D., Togayachi, A., Kudo, T., Watanabe, H., Narimatsu, H. \& Kimata, K. (2003): Chondroitin sulfate synthase-3. Molecular cloning and characterization. - J. Biol. Chem. 278: 39711-39725.

Yoon, H.S., Hackett, J.D., Ciniglia, C., Pinto, G. \& Bhattacharya, D. (2004): A molecular timeline for the origin of photosynthetic eukaryotes. - Mol. Biol. Evol. 21: 809-818.

Zinoun, M., Diouris, M., Potin, P., Floch, J.Y. \& Deslandes, E. (1997): Evidence of sulfohydrolase activity in the red alga Calliblepharis jubata. - Bot. Mar. 40: 49-53.

Manuscript received: 29 January 2015

Accepted: 24 March 2015

The pdf version (Adobe JavaScript must be enabled) of this paper includes an electronic supplement:

Table S1. Characterized enzymes active on sulfated algal polysaccharides.

Please download the electronic supplement and rename the file extension to .zip (For security reasons Adobe does not allow to embed .exe, .zip, .rar etc. files). 